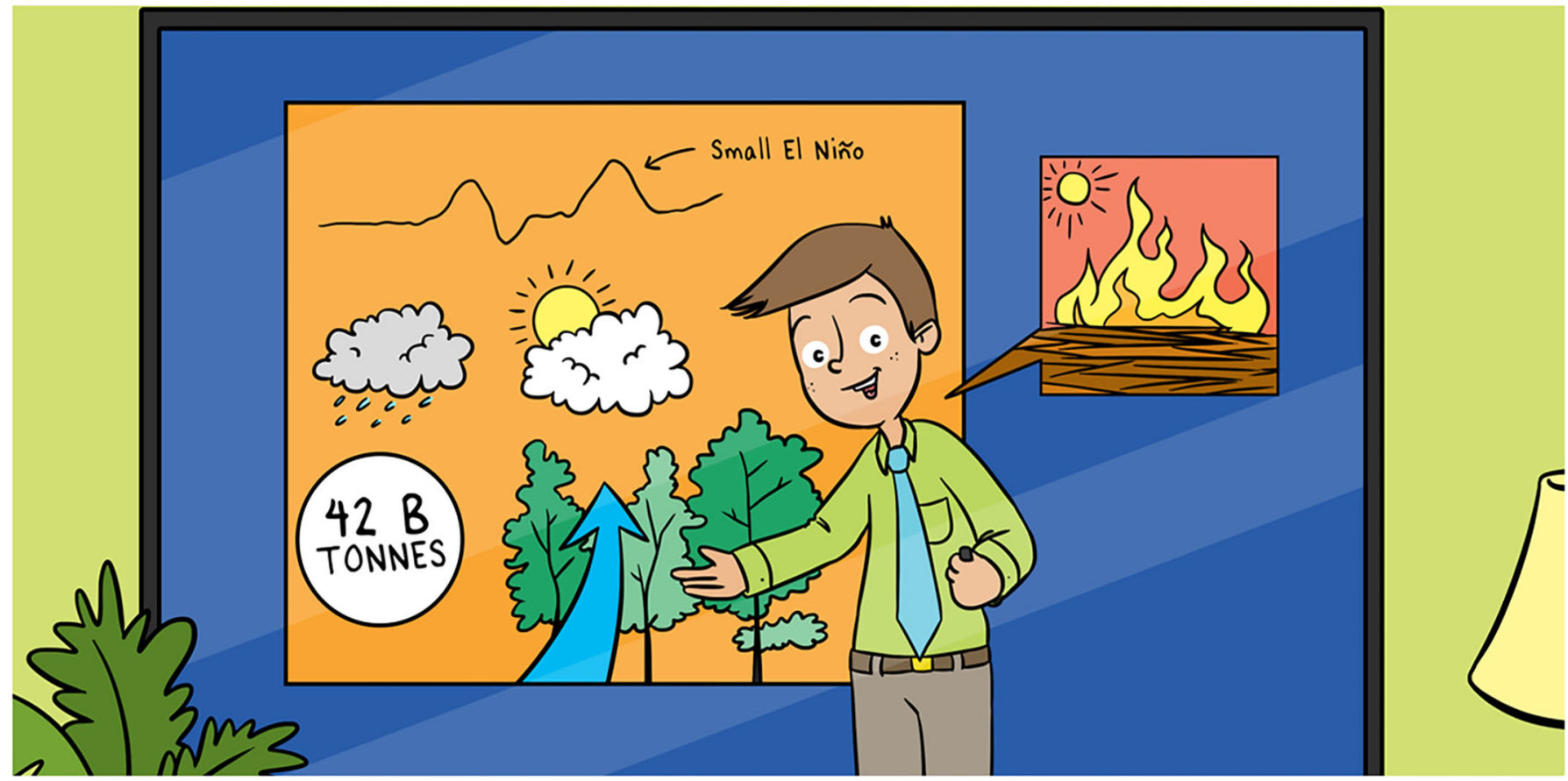

\title{
HOW MUCH $\mathrm{CO}_{2}$ WILL WE HAVE IN THE AIR THIS YEAR?
}

Chris D. Jones ${ }^{1 *}$ and Richard A. Betts ${ }^{1,2+}$

${ }^{1}$ Met Office Hadley Centre, Exeter, United Kingdom

${ }^{2}$ Global Systems Institute, University of Exeter, Exeter, United Kingdom

YOUNG REVIEWERS:

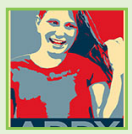

ADDY

AGE: 12

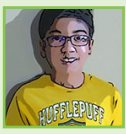

SHANMUKH

AGE: 12

TEDDY

AGE: 9

\section{CARBON DIOXIDE}

$\left(\mathrm{CO}_{2}\right)$

Carbon dioxide $\left(\mathrm{CO}_{2}\right)$ is a gas that contributes to global warming. When we burn fuel (for example to drive cars or to generate power) we put more $\mathrm{CO}_{2}$ into the air, which contributes to climate change. Nature is very good at removing $\mathrm{CO}_{2}$ from the air. Trees need it to grow and the oceans can dissolve it. But not all the new $\mathrm{CO}_{2}$ is removed, so the amount in the air increases each year. Every year, we try to predict how much more $\mathrm{CO}_{2}$ we will have. For an accurate $\mathrm{CO}_{2}$ forecast, we must understand how human activity and natural ecosystems affect each other. In this article, we explain how we can make this forecast. For 2020, we predict that $\mathrm{CO}_{2}$ levels will increase faster than average.

\section{WHAT IS THE CARBON CYCLE?}

Carbon dioxide $\left(\mathrm{CO}_{2}\right)$ exists naturally in the earth's atmosphere. It is a greenhouse gas-you might want to read more about this in Jonny Williams's article [1] which explains more about how this causes 
Figure 1

The global carbon cycle. Trees and plants absorb $\mathrm{CO}_{2}$ and turn it into the carbon they need to grow, through photosynthesis. The carbon returns to the atmosphere as $\mathrm{CO}_{2}$ when dead plants and leaves decay. Oceans absorb carbon and release it back to the atmosphere. Human activities, like burning fossil fuels and cutting down trees, put more $\mathrm{CO}_{2}$ into the atmosphere.

\section{GREENHOUSE GAS}

A gas in the

atmosphere which can absorb heat and cause the planet to warm up. These occur naturally, such as carbon dioxide and water vapor, but human activity is putting more greenhouse gases into the air leading to the planet getting warmer.

\section{CARBON CYCLE}

The movement of carbon through nature-plants absorb $\mathrm{CO}_{2}$ from the air as the grow, and release it again when they die. The water in the oceans dissolves $\mathrm{CO}_{2}$. This cycle is called the carbon cycle.

\section{FOSSIL FUEL}

Fuels, such as coal, oil, and natural gas that were formed millions of years ago when plants and animals died and became buried. Burning fossil fuels creates $\mathrm{CO}_{2}$, which goes into the atmosphere.

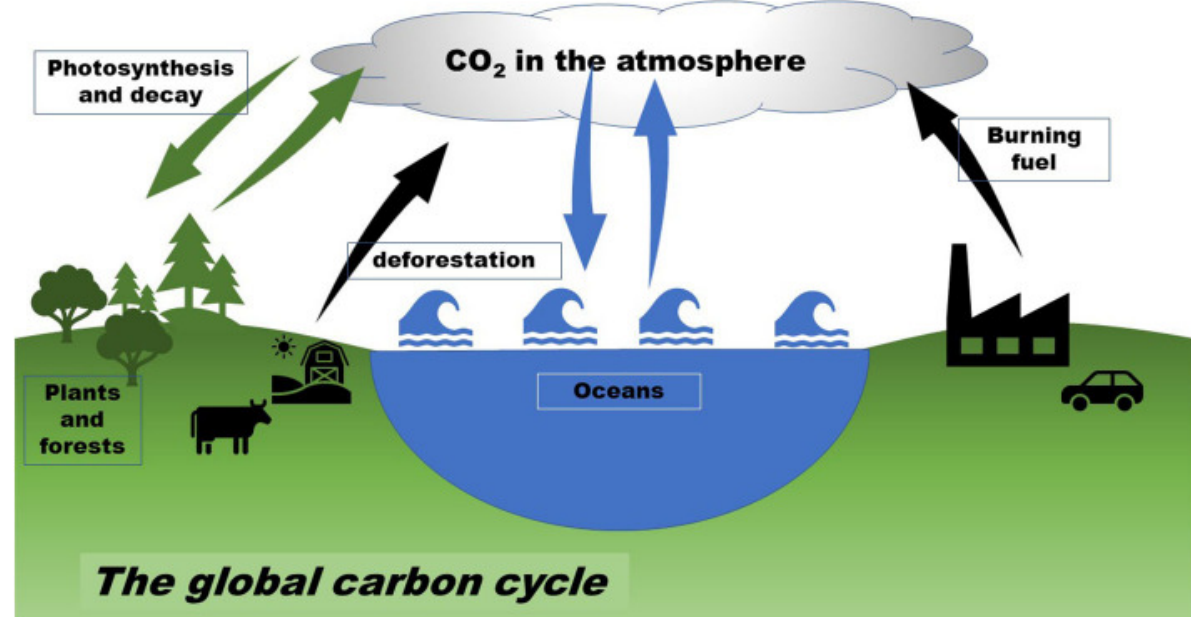

Figure 1

climate change. It is also essential for plants to grow. When plants grow, they absorb $\mathrm{CO}_{2}$ from the air. When they die, the $\mathrm{CO}_{2}$ goes back to the atmosphere. This is known as the carbon cycle. It is a bit like the water cycle, which you probably know about: when it rains on land, the water flows through rivers into the sea. Then it can evaporate again before falling once more as rain. The water just goes round and round in a big cycle.

Something similar happens for $\mathrm{CO}_{2}$ (Figure 1). It can be absorbed by both plants on land and in the ocean (tiny plants called phytoplankton). Via photosynthesis, plants turn the $\mathrm{CO}_{2}$ into the carbon needed to grow their trunks, leaves, or bodies. When the plants die, the carbon goes into the soil where bacteria and microbes eat it and turn it back into $\mathrm{CO}_{2}$. Before humans began to burn lots of fossil fuels about 200 years ago, the total amount of carbon in the cycle remained the same. But now, humans have added more carbon to the carbon cycle by cutting down trees, called deforestation, and burning coal and oil.

\section{HOW HAS $\mathrm{CO}_{2}$ IN THE AIR CHANGED OVER HISTORY?}

In 1958, scientists started to measure the $\mathrm{CO}_{2}$ in the air directly. For thousands of years, it was constant. If you examined one million molecules of air, 280 of these would be $\mathrm{CO}_{2}$. We call this parts per million (ppm). So, we would say that the $\mathrm{CO}_{2}$ concentration for many years was 280 ppm. About 200 years ago as industrialization began, humans started to cut down more and more forests and to burn fossil fuels, like coal and gas. These activities put more $\mathrm{CO}_{2}$ into the air. Since about 1850, the concentration of $\mathrm{CO}_{2}$ in the air has increased. Scientists first measured $\mathrm{CO}_{2}$ in the air in Mauna Loa, Hawaii, where there is an observatory on top of a large volcano. This is a good place to measure $\mathrm{CO}_{2}$ because it is away from large land areas where there 
Figure 2

$\mathrm{CO}_{2}$ is measured in the air at an observatory in Mauna Loa, Hawaii (photograph), by scientists from the Scripps Institute of Oceanography. ${ }^{1}$ The graph shows that $\mathrm{CO}_{2}$ has increased from about 280 ppm before human activity started to put lots more $\mathrm{CO}_{2}$ into the air, to more than 410 ppm in 2020.

1 You can see this figure, and the latest measurements on their website here: https:// scripps.ucsd. edu/programs / keelingcurve/

\section{EL NIÑO}

A weather pattern that happens approximately every 4 years. The temperature of the Pacific Ocean gets warmer and this leads to hotter and drier weather in many regions. The opposite pattern is called La Niña, which leads to cooler temperature around the world

\section{GROWTH RATE (OF} $\left.\mathrm{CO}_{2}\right)$

We know that there is more $\mathrm{CO}_{2}$ in the air every year, because we can measure it. But some years it increases faster than others. The amount that it changes is called the "growth rate".

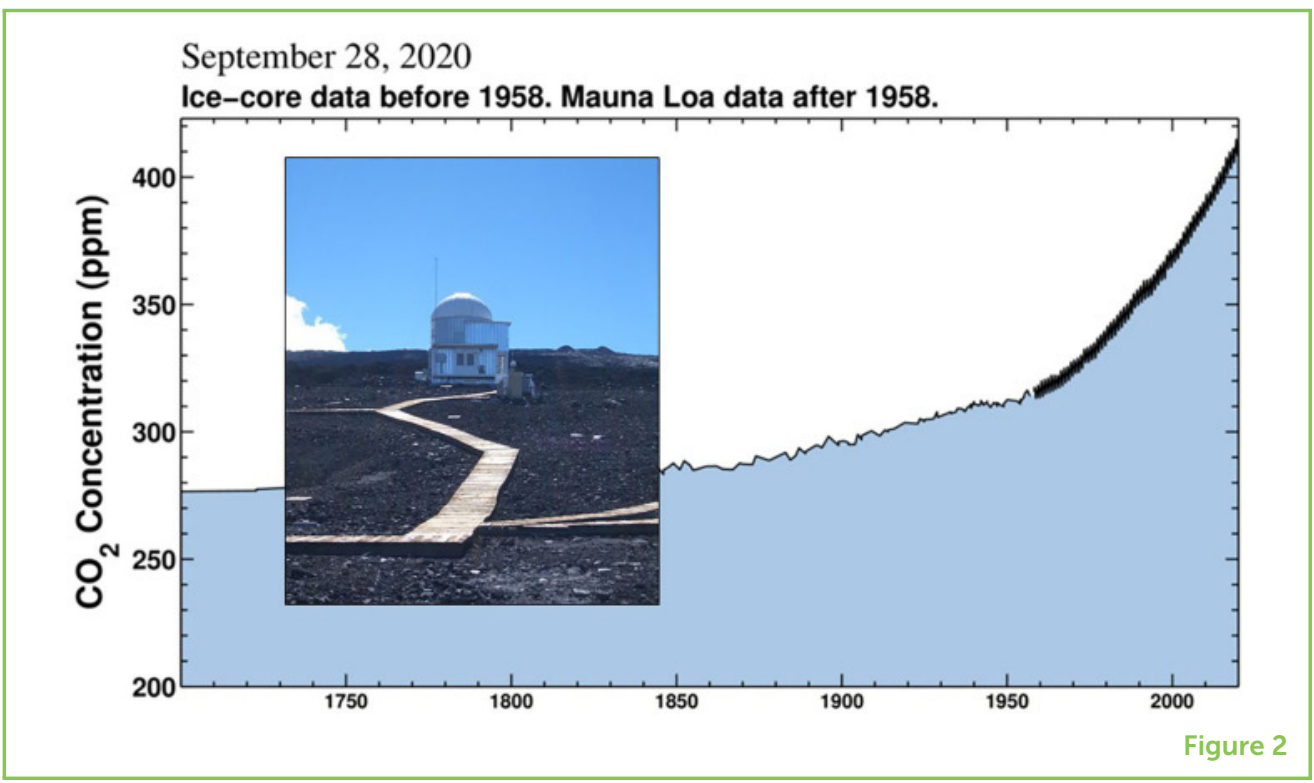

is more pollution. A famous scientist called Charles Keeling kept these measurements going [2] and now we can see that, since 2016, $\mathrm{CO}_{2}$ has reached more than 410 ppm (Figure 2). This is the main reason our climate has warmed by about $1^{\circ} \mathrm{C}$ since the industrial revolution.

\section{WHAT MAKES THE AMOUNT OF $\mathrm{CO}_{2}$ IN THE ATMOSPHERE CHANGE?}

We know that human activity puts more $\mathrm{CO}_{2}$ in the atmosphere, but we also know that the carbon cycle removes some of it. This makes it quite complicated to understand how much more $\mathrm{CO}_{2}$ will continue to be added to the air. Scientists have worked very hard to measure what is happening with $\mathrm{CO}_{2}$, and now we know that about half of the $\mathrm{CO}_{2}$ emissions stay in the air. Plants and oceans absorb the rest. In other words, if we burn fossil fuels and create 4 tons of $\mathrm{CO}_{2}$, then about 2 tons will stay in the air, 1 ton will be absorbed by plants, and 1 ton by the oceans.

We know that the amount of $\mathrm{CO}_{2}$ in the air increases every year. This trend is caused by people burning fuels and cutting down trees. We can also see that, in some years, $\mathrm{CO}_{2}$ increases more quickly than in others. This is true even if the amount of fuel we burn is about the same, and results from different types of weather. Some years are hot and some are cold. Weather differences can change the amount of $\mathrm{CO}_{2}$ that is absorbed. A weather pattern called El Niño happens approximately every 4 years, making some places hotter and drier than normal. The warmer weather can slow down plant growth and cause more fires, which means more $\mathrm{CO}_{2}$ in the air than normal. Figure 3 shows the changes in $\mathrm{CO}_{2}$ each year-we call this the growth rate. In hot years, the growth rate is greater than in cold years. 
Figure 3

The $\mathrm{CO}_{2}$ growth rate, which is the amount that $\mathrm{CO}_{2}$ in the air increases every year, is shown with a black line The blue line shows how much the tropical Pacific Ocean

temperature is above or below normal. You can see that $\mathrm{CO}_{2}$ increases by about 2 ppm each year, with an average growth of $1.6 \mathrm{ppm}$ per year over this whole period. Since 2000 , the average growth rate was 2.2 ppm per year. Hot years caused by El Niño lead to greater $\mathrm{CO}_{2}$ growth, as you can see by the red arrows.

\section{$\mathrm{CO}_{2}$ FORECASTING}

We know that the amount of $\mathrm{CO}_{2}$ in the air will increase every year, but we do not know exactly how much. We use our knowledge of the carbon cycle to predict how much more $\mathrm{CO}_{2}$ we will get. This is our $\mathrm{CO}_{2}$ forecast.

2 You can see the forecast for this year (2020)

here: https:// www. metoffice. gov.uk/

research/

climate/

seasonal-todecadal/longrange/

forecasts/co2forecast

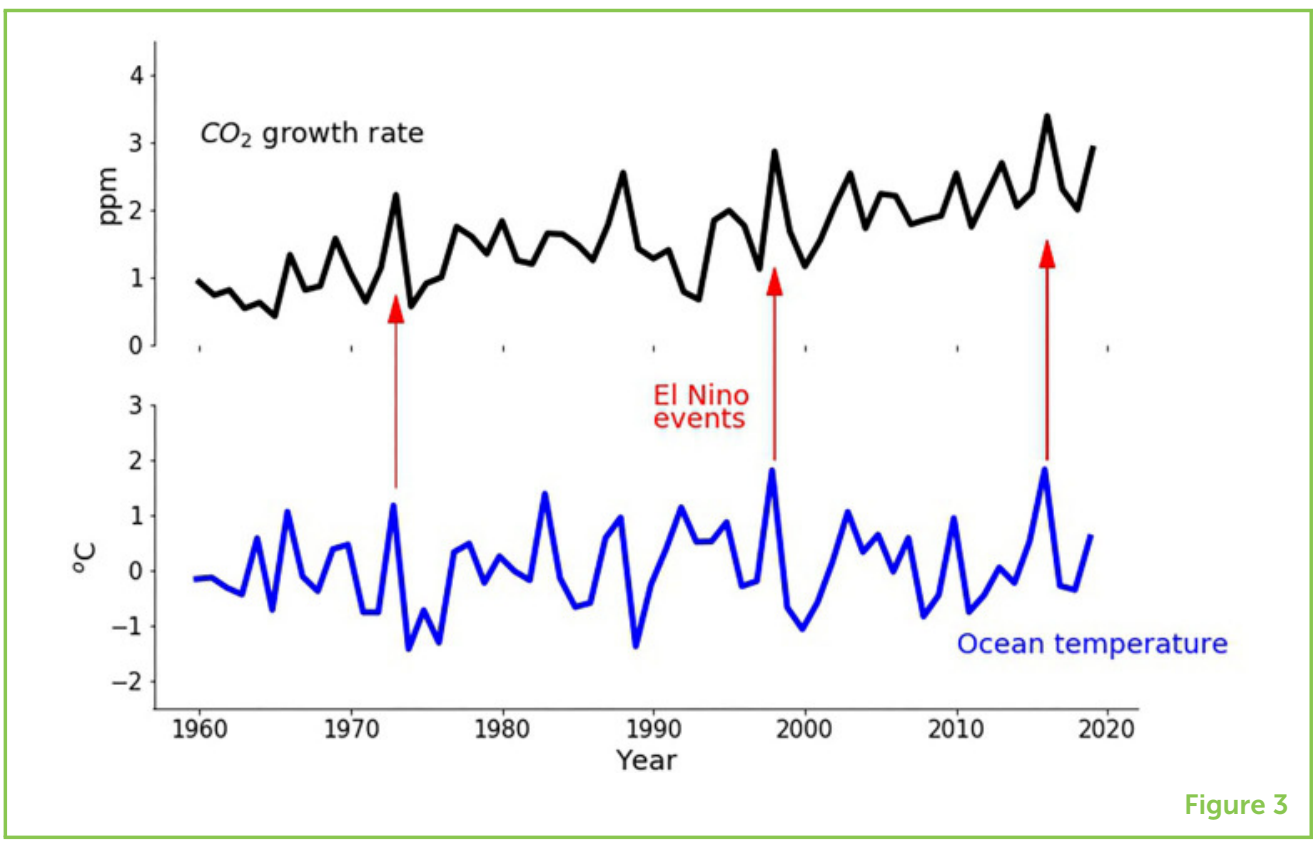

\section{$\mathrm{CO}_{2}$ FORECASTING}

The process of predicting how much $\mathrm{CO}_{2}$ will end up in the air each year is called $\mathrm{CO}_{2}$ forecasting. For accurate $\mathrm{CO}_{2}$ forecasting, we must understand three processes: how much fuel the world is using, how much forest is being cut down, and how the weather will change natural processes.

At the end of 2015, we knew from seasonal weather forecasts that a big El Niño was going to happen. So, we expected that $\mathrm{CO}_{2}$ in the air would grow more quickly than ever before. We made a forecast and wrote a paper about this [3]. At the end of 2016, we measured the $\mathrm{CO}_{2}$ at Mauna Loa to check whether our forecast was right. It turned out we had correctly predicted the biggest $\mathrm{CO}_{2}$ increase ever seen, and that $\mathrm{CO}_{2}$ was now more than 400 ppm. Now, every year, we repeat our $\mathrm{CO}_{2}$ forecast for the next year. ${ }^{2}$

For 2020, our seasonal forecast predicts that there will be a small $\mathrm{El}$ Niño. This means $\mathrm{CO}_{2}$ will grow faster than usual, but it will not be a record. If our forecast is correct, it will be the fourth biggest increase seen in $\mathrm{CO}_{2}$. We also expect that the world will burn about the same amount of fuel as last year [4], releasing about 42 billion tons of $\mathrm{CO}_{2}$, which is more than 5 tons of $\mathrm{CO}_{2}$ for every person in the world! When we combine these facts, we can predict that $\mathrm{CO}_{2}$ will increase by 2.74 ppm and the average for 2020 will be $414.2 \mathrm{ppm}$. This is the highest $\mathrm{CO}_{2}$ level for over a million years.

You may have seen the news that Australia had some very hot weather at the end of 2019 and early 2020, which led to some huge fires. The fires affected lots of people, homes, and animals, but they also burnt down many trees, which put more $\mathrm{CO}_{2}$ in the atmosphere. We can use 
3 https://www . carbonbrief. org/analysiswhat-impactwill-thecoronaviruspandemic-haveon-atmospheric$\mathrm{co} 2$

\section{CARBON BUDGET}

We know that putting more $\mathrm{CO}_{2}$ into the air causes climate change. By understanding how the carbon cycle works we can work out how much $\mathrm{CO}_{2}$ will cause a dangerous level of climate change. We need to make sure that we burn less fossil fuel than this amount of carbon-which we call the carbon budget. satellites to measure how many fires there were and to estimate how much $\mathrm{CO}_{2}$ this caused. From our analyses, we think that these fires made the $\mathrm{CO}_{2}$ increase about $2 \%$ faster than previous years. We also know that people have used less fuel, especially for transport, because of the Covid-19 pandemic. This means $\mathrm{CO}_{2}$ emissions might be a bit smaller in 2020 [5], so we expect about 0.3 ppm smaller growth ${ }^{3}$ of $\mathrm{CO}_{2}$.

\section{WHY IS $\mathrm{CO}_{2}$ FORECASTING IMPORTANT?}

We know that our climate is changing and that these changes are having some devastating effects on people around the world. We have seen more storms, more droughts, and more fires like those in Australia. Some of these might happen anyway, but with climate change we know they will happen more often. We know it is extremely important to try to stop climate change from getting even worse. To stop it from getting too bad, we should all try to reduce the amount of new $\mathrm{CO}_{2}$ we put in the air. If we can understand how natural processes take $\mathrm{CO}_{2}$ out of the atmosphere, then we can calculate how much we must reduce our use of fuel. We call this a carbon budget. You might have a budget for spending your money, which tells you how much to spend on food, clothes, and so on. Scientists can work out a carbon budget, which measures how much fuel we can use before climate change becomes too dangerous.

Our $\mathrm{CO}_{2}$ forecast is part of the research that we need to help understand the global carbon cycle. We now know that we can predict the world's carbon cycle very accurately for 1 year. This will help us improve how we predict $\mathrm{CO}_{2}$ growth for many years in the future, which can help the world plan ways to avoid the dangers of climate change.

\section{STRETCH AND CHALLENGE!}

If you like maths, here is the equation we use to make our forecast.

We add together the $\mathrm{CO}_{2}$ made by burning fossil fuels and deforestation. We call this the emissions, and use the symbol " $E$ ". For 2018, 36.9 billion tons of $\mathrm{CO}_{2}$ came from fossil fuels and 5.5 billion tons from deforestation [4]. So, $E=36.9+5.5=42.4$ billion tons of $\mathrm{CO}_{2}$.

We also need a forecast of the ocean temperatures. We call this " $N$ " to stand for El Niño. The Met Office forecast predicts $N=0.59^{\circ} \mathrm{C}$ for 2020.

Now we can calculate the $\mathrm{CO}_{2}$ growth rate for 2020 using an equation, multiplying $E$ and $N$ by some numbers called coefficients. 
4 Stretch and Challenge Answer: The growth rate would be 2.091 ppm. Did you get it right?
The coefficients were determined by looking at the data for the past and using a mathematical technique called regression.

$\mathrm{CO}_{2}$ growth rate $=0.07+(0.43 \times \mathrm{N})+(0.057 \times \mathrm{E})$

$=0.07+0.25+2.42$

\section{$=2.74 \mathrm{ppm}$}

Now imagine that, in 2021, emissions might increase to 43 billion tons, but maybe we might have a cold La Niña and $N=-1^{\circ} \mathrm{C}$. Can you work out what the $\mathrm{CO}_{2}$ growth rate would be? ${ }^{4}$

\section{REFERENCES}

1. Williams, J. 2020. Computing the climate: building a model world. Front. Young Minds 8:161. doi: 10.3389/frym.2019.00161

2. Keeling, C. D., Piper, S. C., Bacastow, R. B., Wahlen, M., Whorf, T. P., Heimann, M., et al. 2001. "Exchanges of atmospheric $\mathrm{CO}_{2}$ and $13 \mathrm{CO}_{2}$ with the terrestrial biosphere and oceans from 1978 to 2000. I. Global aspects," in SIO Reference Series, No. 01-06 (San Diego, CA: Scripps Institution of Oceanography). p. 88. Available online at: http://escholarship.org/uc/item/09v319r9

3. Betts, R., Jones, C., Knight, J., Keeling, R. F., and Kennedy, J. J. 2016. El Niño and a record $\mathrm{CO}_{2}$ rise. Nat. Clim. Change 6:806-10. doi: 10.1038/nclimate3063

4. Friedlingstein, P., Jones, M. W., O'Sullivan, M., Andrew, R. M., Hauch, J., Peters, G. P., et al. 2019. Global carbon budget 2019. Earth Syst. Sci. Data 11:1783-838. doi: 10.5194/essd-11-1783-2019

5. Le Quéré, C., Jackson, R. B., Jones, M. W., Smith, A. J. P., Abernethy, S., Andrew, R. M., et al. 2020. Temporary reduction in daily global $\mathrm{CO}_{2}$ emissions during the COVID-19 forced confinement. Nat. Clim. Chang. 10:647-53. doi: 10.1038/ s41558-020-0797-x

SUBMITTED: 28 March 2020; ACCEPTED: 22 February 2021;

PUBLISHED ONLINE: 16 March 2021.

EDITED BY: Mirjam Sophia Glessmer, University of Bergen, Norway

CITATION: Jones CD and Betts RA (2021) How Much $\mathrm{CO}_{2}$ Will We Have in the Air This Year? Front. Young Minds 9:546522. doi: 10.3389/frym.2021.546522

CONFLICT OF INTEREST: The authors declare that the research was conducted in the absence of any commercial or financial relationships that could be construed as a potential conflict of interest.

COPYRIGHT @ 2021 Jones and Betts. This is an open-access article distributed under the terms of the Creative Commons Attribution License (CC BY). The use, distribution or reproduction in other forums is permitted, provided the original author(s) and the copyright owner(s) are credited and that the original publication in this journal is cited, in accordance with accepted academic practice. No use, 

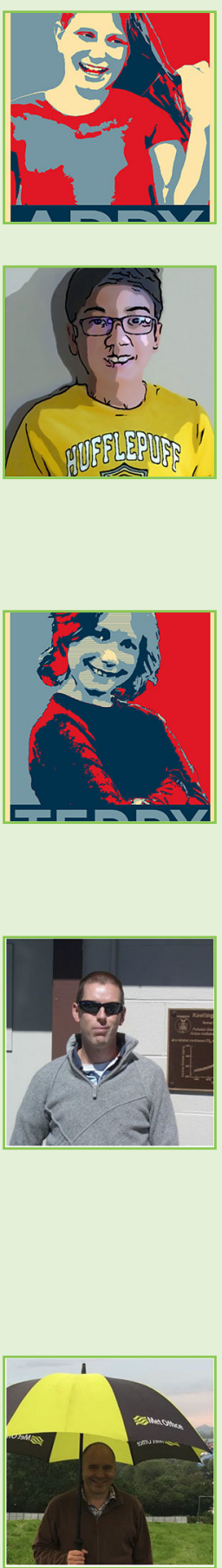

distribution or reproduction is permitted which does not comply with these terms.

\section{YOUNG REVIEWERS}

\section{ADDY, AGE: 12}

I am in sixth grade and really enjoy being on student council. I really like helping animals and I hope to become a veterarian when I get older. My favorite class in school is my dance class (I am very flexible) and I love to travel.

\section{SHANMUKH, AGE: 12}

My name is Shanmukh. I am 12 years old. One of my hobbies is doing crafts. My favorite sport is basketball. I have a great passion for math and science. This summer, I did a project that involved monitoring growth of plants and weather conditions. The different plants I studied included: tomatoes, egg plants, and jalapenos. I am very excited to be a Young Reviewer and thank Frontiers for providing me this opportunity.

\section{TEDDY, AGE: 9}

I want to be an engineer. I have really enjoyed trying and struggling to learn how to engineer and code things. I am dyslexic. I really love math (especially algebra and geometry). I like to travel. I bike 30 miles a week most weeks.

\section{AUTHORS}

\section{CHRIS D. JONES}

Dr. Chris Jones is a climate researcher at the Met Office Hadley Centre in Exeter in the UK. He has over 25 years of experience of writing computer programmes to model how climate affects our natural ecosystems and how the carbon cycle helps reduce the amount of $\mathrm{CO}_{2}$ pollution in the atmosphere. He leads a research programme with partners in Brazil and has visited research sites in the Amazon rainforest. The photo here is on top of the Mauna Loa volcano in Hawaii where $\mathrm{CO}_{2}$ is measured. ${ }^{*}$ chris.d.jones@metoffice.gov.uk; orcid.org/0000-0002-7141-9285

\section{RICHARD A. BETTS}

Professor Richard Betts is a climate researcher at the Met Office Hadley Centre and the University of Exeter, UK. He has 25 years of experience of studying the impacts climate change might have on people and natural ecosystems. He works with other scientists around the world, in areas from the Amazon to the Himalayas, and is the leading scientist for the UK's third official national report on the risks of climate change. He talks about climate change issues through public speeches, social media, and big events like the Glastonbury Festival. He was awarded an MBE at Buckingham Palace for his work on climate science and communication. †orcid.org/0000-0002-4929-0307 